\title{
Maternal and carryover effects on early growth of Eucalyptus globulus
}

\author{
Gustavo A. Lopez, Bradley M. Potts, René E. Vaillancourt, and Luis A. Apiolaza
}

\begin{abstract}
Maternal and nonmaternal reciprocal effects were compared with nuclear genetic and carryover effects using a diallel mating amongst eight Eucalyptus globulus Labill. wild parents from northeastern and southern Tasmania races. Seed mass exhibited a significant maternal effect, increasing seed germinative capacity but not germination rate. After accounting for variation in seed mass, both germinative capacity and germination rate exhibited significant reciprocal effects, but these were nonmaternal in origin. Rapid germination and large seeds resulted in significantly larger seedlings in the nursery, but these carryover effects diminished with age. In contrast, the expression of genetic effects increased with age. Significant additive genetic variation was detected for growth by age 3 years and significant reciprocal differences were detected at the race level after 2 years in field trials. If common, such reciprocal effects could bias genetic parameters and impact on the choice of cross-direction in deployment programs. Failure to account for carryover effects in genetic analyses may inflate estimates of genetic variation for growth during early stages of the life cycle.
\end{abstract}

Résumé : Les auteurs ont comparé les effets réciproques maternels et non maternels aux effets génétiques nucléaires et de transfert à l'aide d'un plan de croisement diallèle impliquant huit parents à l'état sauvage d'Eucalyptus globulus Labill. représentatifs des races du Nord-Est et du Sud de la Tasmanie. La masse des graines a démontré un effet maternel significatif, augmentant la capacité germinative mais pas le taux de germination. Après avoir tenu compte de l'effet de la masse des graines, la capacité germinative ainsi que le taux de germination ont démontré des effets réciproques significatifs sans être d'origine maternelle. Un taux de germination rapide et de grosses graines donnaient des semis significativement plus gros en pépinière, mais ces effets de transfert diminuaient avec l'âge. Au contraire, l'expression des effets génétiques augmentait avec l'âge. Une variation génétique d'origine additive significative a été détectée pour la croissance à l'âge de 3 ans et des différences réciproques significatives ont été détectées au niveau des races dans les dispositifs au champ après 2 ans. Si ces effets réciproques sont courants, ils pourraient biaiser les paramètres génétiques et influencer le choix du sens des croisements lors de la réalisation des programmes de déploiement. La négligence des effets de transfert lors des analyses génétiques peut entraîner des estimations trop élevées de la variation génétique pour la croissance durant les stades juvéniles du cycle de vie.

[Traduit par la Rédaction]

\section{Introduction}

Estimates of additive genetic variation in a population are important for accurate selection and prediction of genetic gain (Lynch and Walsh 1998), but these estimates may be confounded with other sources of environmental or genetic variation (Hodge et al. 1996; Mazer and Gorchov 1996; Lynch and Walsh 1998; Shaw and Byers 1998). Such con-

Received 25 April 2002. Accepted 20 May 2003. Published on the NRC Research Press Web site at http://cjfr.nrc.ca on 22 October 2003.

G.A. Lopez. Cooperative Research Centre for Sustainable Production Forestry and School of Plant Science, University of Tasmania, Private Bag 55, Hobart, 7001, Tasmania, Australia, and Instituto Nacional de Tecnología Agropecuaria (INTA) CIRN, Los Reseros y Las Cabañas s/n, 1712, Castelar (B. A.), Argentina.

B.M. Potts, ${ }^{1}$ R.E. Vaillancourt, and L.A. Apiolaza. Cooperative Research Centre for Sustainable Production Forestry and School of Plant Science, University of Tasmania, Private Bag 55, Hobart, 7001, Tasmania, Australia.

${ }^{1}$ Corresponding author (e-mail: B.M.Potts@utas.edu.au). founding may lead to overestimation of the additive genetic variance, and maternal effects are a case in point (Shaw and Waser 1994; Lynch and Walsh 1998; Shaw and Byers 1998). Maternal effects have been widely reported in plants and may influence offspring vigour and fitness (Roach and Wulff 1987; Byers et al. 1997; Lipow and Wyatt 1999). These effects may be either genetically or environmentally based and are signalled when the maternal effect on offspring performance exceeds the 50\% expectation from Mendelian inheritance (Lacey 1998). Maternal genetic effects may be due to the greater maternal nuclear contribution to the endosperm, nuclear maternal effects such as those influenced by seed coat and integument genes, extranuclear maternal effects such as those derived from the chloroplast or mitochondrial genome, and nongenetic effects including epigenetic as well as biotic and abiotic environmental effects (Roach and Wulff 1987; Schmid and Dolt 1994; Mazer and Gorchov 1996; Lacey 1998; Agrawal 2001).

Most studies of maternal effects on plants have focused on characters expressed early in the life cycle, such as seed mass or seed size (reviewed in Mazer and Wolfe 1998) and dormancy and germination (e.g., Schmid and Dolt 1994). Although they are most common in the early stages of the 
life cycle (e.g., Roach and Wulff 1987), maternal effects can persist into adulthood (e.g., Helenurm and Scaal 1996) and even flow across generations (e.g., Byers et al. 1997). These effects may result from direct or indirect causes. For example, maternal effects on traits such as seed size and germination are common, and because they can greatly affect early seedling growth (Roach and Wulff 1987), they may indirectly persist into later stages of the life cycle (herein termed "carryover effects").

Studies of direct and indirect maternal effects in plants have focused on short-lived annuals (e.g., Helenurm and Scaal 1996; Byers et al. 1997), and there are relatively few studies of long-lived forest trees. Nevertheless, these studies have demonstrated that the environment experienced by parents in a seed orchard may affect the expression of phenotypic variation in the subsequent generation used for deployment (termed "seed aftereffects") (Andersson 1994; Stoehr et al. 1998). The importance of maternal effects in the genetic architecture of forest tree species is also being increasingly studied as tree breeding enters advanced generations (e.g., van Wyk 1976, 1977, 1990; Wu and Matheson 2001).

We examined maternal and nonmaternal (i.e., unexplained differences between reciprocal crosses) reciprocal effects on nursery and early field height growth of a forest tree, Eucalyptus globulus Labill. Eucalyptus globulus is a genetically diverse species native to southeastern Australia (Dutkowski and Potts 1999). Because it is in the early stages of domestication, most genetic studies of this species have utilized open-pollinated progenies derived from natural stands (reviewed in Lopez et al. 2002). In these open-pollinated progenies, the pollen parents are unknown and the female environments may differ markedly. Most programs entering advanced generation breeding are based on selecting superior genotypes in control-pollinated progeny tests or grafted arboreta (Borralho 2001). This allows separation of additive and nonadditive genetic effects and more efficient capture of these genetic effects through the deployment of families propagated through mass controlled pollination (Leal and Cotterill 1997; Harbard et al. 1999; Williams et al. 1999). However, a key element in the economics of these new seed production systems is the need to capture specific combining effects and to understand the impact of maternal genotype or maternal environment on progeny performance.

We used a full diallel mating design to assess nuclear and maternal effects on seed characteristics and early seedling performance. Because seed mass, seed size, germination, and early seedling growth are correlated in this species (Martins-Corder et al. 1998; Lopez et al. 2000; Watson et al. 2001), we separated the indirect effects of seed and germination traits from the expression of direct genetic and maternal effects through nursery and early field growth phases.

\section{Materials and methods}

\section{Plant material and crosses}

The $8 \times 8$ full diallel crossing design used for this study was conducted in the summer of 1997-1998. All possible crosses amongst eight parents were carried out, including reciprocal crosses. This was mainly accomplished using the three-visit pollination procedure (Williams et al. 1999). The parents were samples of trees in native stands of E. globulus from the northeastern Tasmania race and the southern Tasmania races (following Dutkowski and Potts 1999). Because the parental trees were more than $10 \mathrm{~km}$ apart, they were treated as unrelated.

In addition to the nuclear genetic differences amongst parental trees, extranuclear genetic differences were maximized because parents had extremely divergent chloroplast DNA (cpDNA) haplotypes. Following the classification of Freeman et al. (2001), all four parent trees from southern Tasmania had cpDNA haplotypes belonging to the southern clade $\left(J_{\mathrm{s}}\right)$, whereas three trees from northeastern Tasmania had cpDNA haplotypes belonging to the central clade $\left(\mathrm{J}_{\mathrm{c}}\right)$. The remaining northern tree had a rare eastern cpDNA haplotype $\left(\mathrm{J}_{\mathrm{et}}\right)$, phylogenetically related to but distinctive from those of the $J_{c}$ clade (Table 1). Because the inheritance of the cpDNA genome in E. globulus is maternal (McKinnon et al. 2001), the crossing scheme generated reciprocal interrace hybrid families possessing on average the same nuclear genetic complement but with different chloroplast haplotypes in reciprocal families (Table 1).

Capsules derived from controlled crosses and open pollinations were harvested from each female in December 1998. No seeds were obtained from one tree (655), as all flowers aborted. Pollen collected from this tree was successfully used in crossing onto other trees. For each capsule harvested, seed mass was estimated as the total mass of viable seed divided by the number of viable seed counted. This trait, hereafter referred to as seed mass (sdm), constitutes the first early character analysed in this study.

\section{Germination and nursery growth}

From each of the crosses derived from the diallel mating, a sample of up to 40 seeds was selected from one or more seed capsules and used in the germination trial. The full-sib and open-pollinated seed lots (families) were sown in a randomized complete block design with two blocks. From each seed lot, up to 20 seeds from a single capsule were sown in a 10-cm-diameter plastic pot with a vermiculite seedbed. Normally, the two replicates were from different capsules. However, for those families with fewer than 20 seeds per capsule, extra capsules were sown into other pots. These pots were allocated to additional incomplete replicates until the complete 40 seeds per family were sown, or as many as were available. The fact that each pot contained seeds from only one capsule allowed us to track each capsule, and hence average seed mass, throughout the experiment. Germination was counted 12 and 20 days after sowing. Germinative capacity was measured as the proportion of seed sown that had germinated (i.e., radicle emerged from the seed) by day 20 . The proportion of plants with cotyledons fully expanded at day 12 divided by the proportion of seed germinated at day 20 was used as an estimate of the speed of germination (germination rate).

About 3 weeks after peak germination, seedlings were individually pricked out into pots $(12 \mathrm{~cm}$ deep) containing a mix of peat, perlite, and fertilizer, keeping track of their pedigree and germination replicate (and hence capsule identity). Three weeks later, seedlings within each family were ran- 
Table 1. Diallel crossing design with the total number of Eucalyptus globulus plants in trials by female and male race (northeastern Tasmania (north) and southern Tasmania (south)) and parent tree identification.

\begin{tabular}{|c|c|c|c|c|c|c|c|c|c|c|c|c|}
\hline & \multirow[b]{2}{*}{$\begin{array}{l}\text { Tree } \\
\text { ID }\end{array}$} & \multirow[b]{2}{*}{ Clade } & \multicolumn{4}{|c|}{ Male north } & \multicolumn{4}{|c|}{ Male south } & \multirow[b]{2}{*}{ OP } & \multirow[b]{2}{*}{ Total } \\
\hline & & & $\begin{array}{l}655 \\
\mathrm{~J}_{\mathrm{c}} \\
\end{array}$ & $\begin{array}{l}656 \\
\mathrm{~J}_{\mathrm{c}} \\
\end{array}$ & $\begin{array}{l}657 \\
\mathrm{~J}_{\mathrm{et}} \\
\end{array}$ & $\begin{array}{l}658 \\
\mathrm{~J}_{\mathrm{c}} \\
\end{array}$ & $\begin{array}{l}529 \\
\mathrm{~J}_{\mathrm{s}} \\
\end{array}$ & $\begin{array}{l}536 \\
\mathrm{~J}_{\mathrm{s}} \\
\end{array}$ & $\begin{array}{l}659 \\
\mathrm{~J}_{\mathrm{s}} \\
\end{array}$ & $\begin{array}{l}660 \\
\mathrm{~J}_{\mathrm{s}} \\
\end{array}$ & & \\
\hline \multirow[t]{3}{*}{ Female north } & 656 & $\mathrm{~J}_{\mathrm{c}}$ & & & & & & & 23 & & 35 & 58 \\
\hline & 657 & $\mathrm{~J}_{\mathrm{et}}$ & 18 & 34 & & 13 & 29 & 41 & 23 & 23 & 27 & 208 \\
\hline & 658 & $\mathrm{~J}_{\mathrm{c}}$ & 23 & 9 & 35 & & & 64 & & 11 & 25 & 167 \\
\hline \multirow[t]{4}{*}{ Female south } & 529 & $\mathrm{~J}_{\mathrm{s}}$ & 34 & 34 & 34 & 25 & & 35 & 35 & 36 & 26 & 259 \\
\hline & 536 & $\mathrm{~J}_{\mathrm{s}}$ & 35 & 31 & 65 & 64 & 35 & & 35 & 35 & 28 & 328 \\
\hline & 659 & $\mathrm{~J}_{\mathrm{s}}$ & 29 & & 32 & 26 & 35 & & & 29 & 31 & 182 \\
\hline & 660 & $\mathrm{~J}_{\mathrm{s}}$ & 35 & 26 & 10 & & 32 & 11 & 33 & & 27 & 174 \\
\hline Total & & & 174 & 134 & 176 & 128 & 131 & 151 & 149 & 134 & 199 & 1376 \\
\hline
\end{tabular}

Note: All flowers from open-pollinated (OP) and control-pollinated crosses on tree ID 655 were aborted. The haplotype of the partent trees is indicated as belonging to either the central clade $\left(\mathrm{J}_{\mathrm{c}}\right)$, southern clade $\left(\mathrm{J}_{\mathrm{s}}\right)$, or eastern clade $\left(\mathrm{J}_{\mathrm{et}}\right)$.

domly allocated into a nursery experiment consisting of 36 randomized blocks of single-tree plots. Families with an insufficient number of trees for a complete replication were randomly allocated to plots. Seedlings were grown in the glasshouse for 26 weeks and then gradually hardened off by moving them into a shade house and then outdoors. The experimental design was maintained when the seedlings were moved. Individual plant height was measured at 9 and 20 weeks of age (hereafter referred to as 2 and 5 months).

\section{Field trials}

Two field trials were established when seedlings were 6 months old. In each case, the germination and nursery replicate of each seedling was tracked into the field to allow matching individual field performance with seed mass, germinative capacity, germination rate, and nursery performance. Two sites were selected: one in eastern Tasmania (Weilangta) $\left(42^{\circ} 44^{\prime} 44^{\prime \prime} \mathrm{S}, 147^{\circ} 49^{\prime} 25^{\prime \prime} \mathrm{E}\right)$ and the other in southern Tasmania (Geeveston) $\left(43^{\circ} 09^{\prime} 40^{\prime \prime} \mathrm{S}, 146^{\circ} 51^{\prime} 38^{\prime \prime} \mathrm{E}\right)$. Both sites were ex-native forest. After clear-felling, soil was ripped and mounded into rows $3 \mathrm{~m}$ apart. The plants were planted $3.5 \mathrm{~m}$ apart within rows. The field trials used a randomized block design with single-tree plots. Plants were rerandomized with respect to nursery replicates and imbalance treated as previously described. The number of field replicates at Weilangta was 18 and at Geeveston was 17 . Total plant heights were measured at 1, 10, 22, and 34 months after planting in the field. At these times, the plants were 7, 16,28 , and 40 months old from sowing.

\section{Data analysis}

We analysed the full-sib families to estimate genetic additive, specific combining ability, and reciprocal (maternal and nonmaternal) and carryover effects for growth and how they change over time. The significance of these factors was determined by fitting different linear mixed models to the data using the program ASReml (Gilmour et al. 2001).

\section{Seed mass}

The first analysis examined factors affecting seed mass on a capsule basis using the following model:

$$
\begin{aligned}
y=\mu+F_{\text {race }} & +M_{\text {race }}+F_{\text {race }} \times M_{\text {race }}+\mathrm{GCA} \\
& +\mathrm{SCA}+\text { maternal }+ \text { reciprocal }+e
\end{aligned}
$$

where $y$ is the seed mass per capsule, $\mu$ is the fixed overall mean, $F_{\text {race }}$ and $M_{\text {race }}$ are the fixed effects of female and male race of origin, respectively, $F_{\text {race }} \times M_{\text {race }}$ is the fixed effect of the male and female race of origin interaction term, GCA and SCA are the general and specific combining abilities within races, respectively, "maternal" and "reciprocal" are the terms accounting for the maternal and nonmaternal reciprocal effects, respectively, and $e$ is the residual. All random effects (GCA, SCA, maternal, and reciprocal) refer to variation within fixed race effects. For example, the GCA and SCA effects refer to variation within the levels of $F_{\text {race }}$ and $M_{\text {race }}$. However, it should be noted that the effects relating to the race of origin and the maternal effects do not allow genetic and environmental sources of variation to be separated as parental genotypes were in natural stands and were not randomized or replicated with respect to the environment where crosses were undertaken.

\section{Germination traits}

The second type of analysis examined the significance of factors affecting the germination traits. For these analyses, germination data (i.e., proportions) were transformed with a probit function and weighted by the total number of seeds sown in each pot. We fitted the following mixed model:

$$
\begin{aligned}
y=\mu & +\operatorname{rep}_{\text {sown }}+\mathrm{sdm}+F_{\text {race }}+ \\
\times M_{\text {race }}+\mathrm{GCA}+\mathrm{SCA}+ & \text { maternal } \\
& + \text { reciprocal }+e
\end{aligned}
$$

where rep $_{\text {sown }}$ is a fixed term to account for the replicate allocated for the germination design (only the two most complete replicates were included), sdm is the covariate accounting for seed mass, and the remaining terms are as described for model 1 . The specific traits analysed were the germinative capacity and germination rate.

\section{Growth traits}

Growth traits for total plant height measured in the nursery were analysed using an individual tree model (Borralho 1995): 


$$
\begin{aligned}
y=\mu & + \text { rep }_{\text {nursery }}+\mathrm{sdm}+G_{\text {rate }}+F_{\text {race }}+M_{\text {race }} \\
+ & F_{\text {race }} \times M_{\text {race }}+\text { tree }+\mathrm{SCA}+\text { maternal } \\
& + \text { reciprocal }+e
\end{aligned}
$$

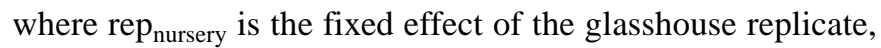
$G_{\text {rate }}$ is the covariate included to account for the importance of seed germination rate on growth in the nursery, tree is the random individual-tree additive genetic effect replacing GCA in model 2, and the remaining terms are as described for models 1 and 2 .

\section{Field growth}

The analysis of field growth was undertaken across sites using the individual-tree model:

$$
\begin{aligned}
y=\mu+\text { site } & +\operatorname{rep}_{\text {field }}+\operatorname{sdm}+G_{\text {rate }}+\text { rep }_{\text {ghouse }} \\
+F_{\text {race }} & +M_{\text {race }}+F_{\text {race }} \times M_{\text {race }}+\text { tree } \\
& +\mathrm{SCA}+\text { maternal }+ \text { reciprocal }+e
\end{aligned}
$$

where site accounts for the fixed difference between the two sites, re $\mathrm{p}_{\text {field }}$ accounts for the fixed difference between field replicates within sites, and the remaining terms are described in previous models. Separate error variances were fitted for each site in model 4 . Starting values for these error variances were obtained from individual site analyses (model 4 excluding the site term). Because the interactions between site and area of origin were very small, they were excluded from the model.

The significances of the fixed effects were tested with $F$ statistics using the appropriate error degrees of freedom. Fixed effects least square means for $F_{\text {race }} \times M_{\text {race }}$ and their standard errors were also estimated in ASReml using the Predict option. Following Gilmour et al. (2001), random effects were treated as significant when the ratio of the variance component to its standard error was larger than $2(Z>$ $2)$ and not significant when the ratio was less than $1(Z<1)$; otherwise, significance was tested using a likelihood ratio test (Searle 1971).

\section{Results}

The only factor that significantly affected seed mass was the maternal reciprocal effect (Table 2), which accounted for $47 \%$ of the random variation within races. Seed mass significantly affected germinative capacity $(P<0.001)$ (Table 2$)$, with lighter seeds tending to have lower percentage germination. After accounting for the effect of seed mass, there was a significant nonmaternal reciprocal effect on germinative capacity $(P<0.001)$ that accounted for $24 \%$ of the random variation and also an effect of female race $(P<0.05)$ (Table 2). The rate of germination was independent of seed mass (i.e., there was a nonsignificant effect of the seed mass covariate). However, there was a significant nonmaternal reciprocal effect $(P<0.001,12 \%$ of random variation) and a significant female race effect $(P<0.001)$. No other factors tested exhibited a significant effect on either germinative capacity or rate. The significant fixed effect of female race was

\begin{tabular}{|c|c|c|c|}
\hline & $\mathrm{sdm}$ & GC & $G_{\text {rate }}$ \\
\hline Source of variation & $Z / F$ & $Z / F$ & $Z / F$ \\
\hline \multicolumn{4}{|l|}{ Random effects (race) } \\
\hline GCA & $0.00 \mathrm{~ns}$ & $0.00 \mathrm{~ns}$ & $1.43 \mathrm{nt}$ \\
\hline SCA & $0.00 \mathrm{~ns}$ & $0.00 \mathrm{~ns}$ & $0.00 \mathrm{~ns}$ \\
\hline Maternal reciprocal & $1.40 * * *$ & $0.00 \mathrm{~ns}$ & $0.00 \mathrm{~ns}$ \\
\hline Nonmaternal reciprocal & $1.98 \mathrm{~ns}$ & $2.47 * * *$ & $2.46 * * *$ \\
\hline Covariate $\mathrm{sdm}$ & & $20.63 * * *$ & $3.54 \mathrm{~ns}$ \\
\hline \multicolumn{4}{|l|}{ Fixed effects } \\
\hline rep $_{\text {sown }}$ & & $6.50 *$ & $0.00 \mathrm{~ns}$ \\
\hline$F_{\text {race }}$ & $0.15 \mathrm{~ns}$ & $5.08^{*}$ & $17.63 * * *$ \\
\hline$M_{\text {race }}$ & $1.33 \mathrm{~ns}$ & $1.97 \mathrm{~ns}$ & $0.89 \mathrm{~ns}$ \\
\hline$F_{\text {race }} \times M_{\text {race }}$ & $0.32 \mathrm{~ns}$ & $0.29 \mathrm{~ns}$ & $0.00 \mathrm{~ns}$ \\
\hline
\end{tabular}
due to the trees from southern Tasmania having significantly higher germinative capacity and rate than those from northern Tasmania (Fig. 1).
Table 2. Factors affecting seed mass (sdm), germinative capacity $(\mathrm{GC})$, and germination rate $\left(G_{\text {rate }}\right)$ in Eucalyptus globulus.

Note: $Z$ values are presented for the random effects, which include general combining ability (GCA), specific combining ability (SCA), maternal reciprocal, and nonmaternal reciprocal effects expressed within races. $F$ values are presented for fixed effects, which include replicate from the germination experiment $\left(\right.$ rep $\left._{\text {sown }}\right)$, terms to account for the female $\left(F_{\text {race }}\right)$ and male $\left(M_{\text {race }}\right)$ race of origin and their interaction $\left(F_{\text {race }} \times M_{\text {race }}\right)$, and the covariate to account for seed mass (sdm). Degrees of freedom for all fixed effects and the covariate are unity. Significance of effects: $*, P<0.05$; **, $P<0.01$; and ***, $P<0.001$; ns, not significant; nt, could not be tested.

Apart from the effect of nursery replicate and the covariates, the only significant factor affecting nursery growth was the nonmaternal reciprocal effect $(P<0.05)$ (Table 3 ). Plant height in the nursery was strongly affected by the covariates germination rate $(2$ months, $P<0.001 ; 4$ months, $P<0.01)$ and seed mass $(P<0.001)$. However, their effects decreased markedly with plant age and were insignificant at field planting (germination rate by 7 months) and the second seasons' field growth (seed mass by 28 months), respectively (Table 3).

Significant environmental effects on growth in the nursery were detected through the replicate effect in the nursery experimental design (Table 3). However, these environmental effects were transient, rapidly became insignificant, and were overshadowed by the increasing significance of the effect of field site and variation between field replicates with age (Table 3).

Neither the effects of female or male race, specific combining ability, nor maternal reciprocal effects had a significant effect on growth at any age (Table 3). The significant nonmaternal reciprocal effects on growth detected in the nursery did not persist beyond the first field measurement. However, genetic effects arising from the interaction between males and females from different races and additive genetic variation within races became significant by 1 year's (16 months of age) and 3 years' (40 months) field growth, respectively. When significant, the additive genetic variation accounted for $9 \%-12 \%$ of the random variation, depending on site. The interaction between males and females from different races was mainly due to slightly faster growth of plants derived from crossing the northern females with the southern males compared with the reciprocal crosses (Fig. 1c). 
Fig. 1. (a) Germinative capacity, (b) germination rate, and (c) tree height least square means of Eucalyptus globulus seed lots that differed in their female and male race of origin $(\mathrm{N}$, northeastern Tasmania; S, southern Tasmania). Female origin is stated first (e.g., $\mathrm{N} \times \mathrm{S}$ ). The effect of female race was significant for germinative capacity $(P<0.05)$ and germination rate $(P<0.001)$. The difference between the four cross types was significant at $16(P<0.05), 28(P<0.01)$, and 40 months of age $(P<0.01)$, and the trends in cross type difference were consistent across all measurement ages.

\section{a) Germinative capacity}

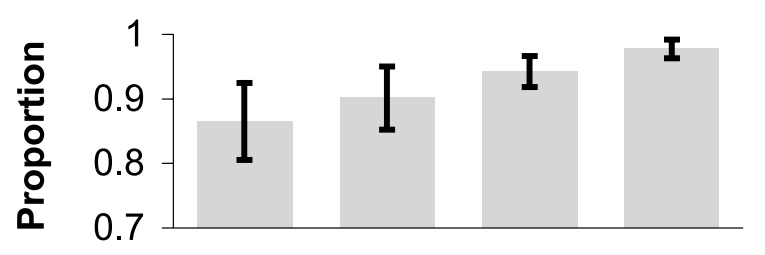

b) Germination rate

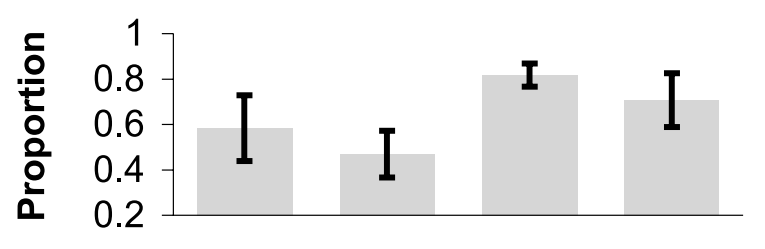

c) Field height age $\mathbf{4 0}$ months

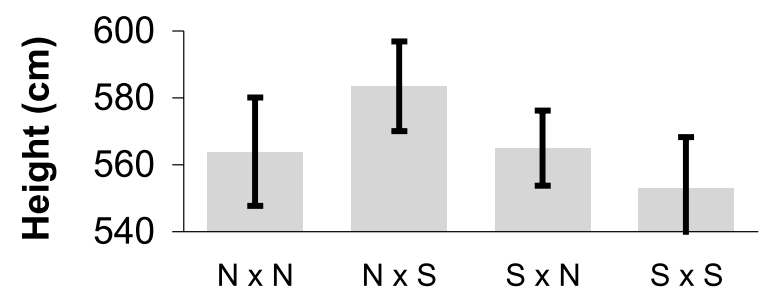

Failure to account for carryover effects of seed mass and germination rate in the statistical model resulted in inflated estimates of the significance of the within-race additive maternal and nonmaternal reciprocal effects. When the two covariates are dropped from the statistical model, these effects are highly significant $(P<0.001)$ as early as the first nursery measurement (data not shown). In this case, the additive genetic effect was significant across all measurements, whereas the maternal effect was insignificant after the second year's field growth (16 months) and the significance of the nonmaternal reciprocal effect did not persist beyond field planting (7 months).

\section{Discussion}

The present study reveals a complex of genetic and nongenetic factors affecting early seedling growth in E. globulus. Early nursery growth was affected by carryover of maternal variation in seed mass as well as carryover of maternal race and nonmaternal reciprocal effects on germination rate. Maternal effects on seed size or seed mass are often highly significant in plants (e.g., Roach and Wulff 1987; Waser et al. 1995; Byers et al. 1997; Lipow and Wyatt 1999), and E. globulus is no exception. Because controlled pollinations were made on trees in native stands, both genetic and environmental factors could affect the variation in seed mass between maternal trees from the different races. For example, maternal variation in altitude at four different sites has been shown to influence seed mass in a closely related species, Eucalyptus nitens (Williams 2000). Variation in seed mass was a major factor affecting the germinative capacity of seed in our experiment. This could reflect the fact that bigger seeds have greater germinative capacity in E. globulus (Martins-Corder et al. 1998; Lopez et al. 2000), as seed density has been shown to have little effect on either germinative capacity or germination time (Watson et al. 2001). There are significant nonmaternal reciprocal effects on both germinative capacity and germination rate that are difficult to explain but may represent within-canopy variation in seed maturation, testa thickness, or physiological status (Roach and Wulff 1987). There was a maternal effect on both germinative capacity and germination rate that was expressed at the racial level and was due to seed from the southern Tasmania trees germinating better and more rapidly than those from the north. Provenance variation in germination response has been reported in other Eucalyptus species (Eucalyptus viminalis, Ladiges 1974; Eucalyptus delegatensis, Battaglia 1997; E. nitens, Humara et al. 2000). Nonetheless, because seeds were harvested from trees in different native stand localities, it is not possible to differentiate genetic from maternal environment effects on germination.

Early seedling growth was strongly and independently affected by seed mass and germination rate but little influenced by genetic or nongenetic factors. Bigger or heavier seeds are well known to produce faster growing seedlings in many plant genera (e.g., Mazer and Gorchov 1996; Byers et al. 1997), including Eucalyptus (Martins-Corder et al. 1998; Lopez et al. 2000; Watson et al. 2001). In the case of Eucalyptus, this association most likely reflects greater resource availability to the developing seedling from larger cotyledons (Boden 1961), which may have adaptive consequences (see Hewitt 1998). In the present study, the carryover effect of variation in seed mass is persistent, lasting 1 year in the field but not 2 years. In Eucalyptus maculata and Eucalyptus sieberiana, seed size affected both germination rate and plant growth, and this effect persisted for at least 16 weeks (Grose and Zimmer 1958). By contrast, the magnitude of the carryover effect of germination rate was only evident in the nursery and more transient than that of seed mass. Similarly, environmental variation in seedling growth rate due to nursery replicate was also small and transitory. The effect of this environmental variation in the nursery was lost after field planting, as large environmentally induced differences in growth rate developed between and within the field sites.

For tree height, our estimates of the additive genetic effects within races did not become significant until 40 months of age. No significant genetic variation in growth was detected at the race level in the nursery or field, but there is evidence for a significant male by female interaction at the 
Table 3. Carryover and other genetic and nongenetic effects on the growth of Eucalyptus globulus.

\begin{tabular}{|c|c|c|c|c|c|c|}
\hline \multirow[b]{3}{*}{ Source of variation } & \multicolumn{2}{|c|}{ Nursery height growth } & \multicolumn{4}{|c|}{ Field height growth } \\
\hline & Nurs 2 & Nurs 4 & Field 7 & Field 16 & Field 28 & Field 40 \\
\hline & $Z / F$ & $Z / F$ & $Z / F$ & $Z / F$ & $Z / F$ & $Z / F$ \\
\hline \multicolumn{7}{|l|}{ Random effects (race) } \\
\hline Tree & $1.15 \mathrm{~ns}$ & $0.48 \mathrm{~ns}$ & $1.05 \mathrm{~ns}$ & $0.76 \mathrm{~ns}$ & $0.82 \mathrm{~ns}$ & $1.26 * * *$ \\
\hline SCA & $0.00 \mathrm{~ns}$ & $0.00 \mathrm{~ns}$ & $0.00 \mathrm{~ns}$ & $1.30 \mathrm{~ns}$ & $1.62 \mathrm{~ns}$ & $0.00 \mathrm{~ns}$ \\
\hline Maternal reciprocal & $0.59 \mathrm{~ns}$ & $0.00 \mathrm{~ns}$ & $0.00 \mathrm{~ns}$ & $0.00 \mathrm{~ns}$ & $0.59 \mathrm{~ns}$ & $0.53 \mathrm{~ns}$ \\
\hline Monmaternal reciprocal & $0.48 \mathrm{~ns}$ & $1.70 *$ & $2.10 * * *$ & $0.00 \mathrm{~ns}$ & $0.00 \mathrm{~ns}$ & $0.50 \mathrm{~ns}$ \\
\hline \multicolumn{7}{|l|}{ Covariates } \\
\hline $\mathrm{sdm}$ & $123.79 * * *$ & $60.45 * * *$ & $22.19 * * *$ & $15.15 * * *$ & $1.13 \mathrm{~ns}$ & $0.81 \mathrm{~ns}$ \\
\hline$G_{\text {rate }}$ & $26.99 * * *$ & $9.34 * *$ & $1.81 \mathrm{~ns}$ & $0.29 \mathrm{~ns}$ & $0.56 \mathrm{~ns}$ & $0.31 \mathrm{~ns}$ \\
\hline \multicolumn{7}{|l|}{ Fixed effects } \\
\hline rep nursery $_{\text {}}$ & $1.87 * *$ & $1.90 * * *$ & $3.61 * * *$ & $1.11 \mathrm{~ns}$ & $0.88 \mathrm{~ns}$ & $0.81 \mathrm{~ns}$ \\
\hline Site & & & $10.33 * *$ & $591.62 * * *$ & $891.74 * * *$ & $132.88 * * *$ \\
\hline rep $_{\text {field }}$ & & & $1.29 \mathrm{~ns}$ & $4.10 * * *$ & $4.84 * * *$ & $8.07 * * *$ \\
\hline$F_{\text {race }}$ & $0.09 \mathrm{~ns}$ & $3.85 \mathrm{~ns}$ & $1.36 \mathrm{~ns}$ & $0.99 \mathrm{~ns}$ & $3.13 \mathrm{~ns}$ & $0.88 \mathrm{~ns}$ \\
\hline$M_{\text {race }}$ & $2.01 \mathrm{~ns}$ & $3.12 \mathrm{~ns}$ & $2.03 \mathrm{~ns}$ & $0.74 \mathrm{~ns}$ & $0.18 \mathrm{~ns}$ & $0.22 \mathrm{~ns}$ \\
\hline$F_{\text {race }} \times M_{\text {race }}$ & $0.68 \mathrm{~ns}$ & $2.94 \mathrm{~ns}$ & $0.91 \mathrm{~ns}$ & $4.76^{*}$ & $6.80 * *$ & $6.76 * *$ \\
\hline
\end{tabular}

Note: The significance of effects that affected height growth at 2 and 5 months in the nursery (nurs 2 and nurs 5 ) and $7,16,28$, and 40 months in the field (field 7, field 16, field 28, and field 40) are indicated. $Z$ values are provided for random effects within race including individual additive genetic (tree), specific combining ability (SCA), maternal reciprocal, and nonmaternal reciprocal effects. Also included are the $F$ values for the covariates seed mass (sdm) and germination rate $\left(G_{\text {rate }}\right)$ and the fixed effects of nursery replicate (rep $\left.F_{\text {nursery }}\right)$, field site (site), replicate within field trials $\left(\right.$ rep $\left._{\text {field }}\right)$, and the female $\left(F_{\text {race }}\right)$ and the male $\left(M_{\text {race }}\right)$ race of origin and their interaction $\left(F_{\text {race }} \times M_{\text {race }}\right)$. Significance of effects: *, $P<0.05 ; * *, P<0.01$; and $* * *, P<0.001$; ns, not significant. The degrees of freedom for the fixed effects and covariates are all 1 except for rep field that is nested within site (33) and rep nursery (35).

racial level. These effects are unlikely to reflect the carryover effects discussed previously because the carryover effects decrease with age, whereas the additive and interaction effects appear to increase with age. This age trend suggests that the interaction is the expression of a genetic effect that (because of its reciprocal nature) may reflect some form of cytonuclear interaction (Cruzan and Arnold 1999). However, as this result is based on only eight parents, the significance of these effects require testing with a larger number of parents, preferably from a common environment.

\section{Implications}

Our study suggests that female-based heritability estimates for very early growth in E. globulus (e.g., openpollinated progenies; reviewed in Lopez et al. 2002) may partly reflect genetic or nongenetic carryover effects of seed mass. Seed mass, for example, exhibits a significant maternal effect and has a persistent carryover effect on early growth. These carryover effects suggest that very early selection for growth is unwise, unless seed mass is accounted for. In addition, these carryover effects could also inflate early-age heritability estimates. However, such carryover effects are unlikely to bias later estimates of heritability in the field because they are transient and the general trend is for an increase, rather than a decrease, in heritability for growth with age in forest trees, including E. globulus (Lopez et al. 2002).

The carryover effects of environmental variation in the nursery on early growth have been a concern because seedlings are often grown in family blocks in the nursery. Be- cause each family is grown in a different position in the nursery, it is possible that environmental effects could be carried over into the field and be confounded with estimates of genetic effects. This could cause an inflation of the estimates of additive genetic variation and specific combining ability in open-pollinated and factorial matings, respectively. Nonetheless, the present study shows that nursery environmental effects may be small and do not persist in the field.

Dominance effects on growth can be comparable with additive genetic effects in E. globulus (Vaillancourt et al. 1995; Hodge et al. 1996). Therefore, exploitation of these effects through the deployment of elite full-sib families is being considered (e.g., Leal and Cotterill 1997). These effects are estimated from specific combining ability deviations of single families without consideration of the directionality of the cross. If maternal or nonmaternal reciprocal effects on growth are significant, these effects will be confounded with estimates of specific combining ability effects in crossing designs such as factorial matings where reciprocal crosses are not included. In the present case, the specific combining ability effect is estimated using both reciprocal crosses in most cases and is insignificant. Nonetheless, there is some evidence for a reciprocal effect, at least at the racial level. The possibility of reciprocal effects on later age growth has implications for programs aimed at deploying elite full-sib families identified in field tests because the crosses would need to be produced for deployment in the same direction as initially tested. Because such a deployment method is becoming more widely used in E. globulus, reciprocal effects on growth clearly require more detailed investigation. 


\section{Acknowledgments}

We thank Forestry Tasmania and Gunns Ltd. for providing field sites and G. Dutkowski, A. Gilmour, G. Jordan, D. Williams, and $\mathrm{H}$. $\mathrm{Wu}$ for discussions and assistance with setting the statistical models. P. Tilyard and P. Black undertook crosses. G.A.L. thanks the University of Tasmania, the Instituto Nacional de Tecnología Agropecuaria, and Argentinean Government for a postgraduate scholarship. This paper is part of G.A.L.'s postgraduate studies.

\section{References}

Agrawal, A.A. 2001. Transgenerational consequences of plant responses to herbivory: an adaptive maternal effect? Am. Nat. 157: 555-569.

Andersson, B. 1994. Aftereffects of maternal environment on autumn frost hardiness in Pinus sylvestris seedlings in relation to cultivation techniques. Tree Physiol. 14: 313-322.

Battaglia, M. 1997. Seed germination model for Eucalyptus delegatensis provenances germinating under conditions of variable temperature and water potential. Aust. J. Plant Physiol. 24: 69-79.

Boden, R.W. 1961. Australian studies on Eucalyptus seed 195661 , with particular reference to germination behaviour. In Second World Eucalyptus Conference, Sao Paulo, Brazil. Food and Agriculture Organization, Rome.

Borralho, N.M.G. 1995. The impact of individual tree mixed models (BLUP) in tree breeding strategies. In Eucalypt Plantations: Improving Fibre Yield and Quality. Proceedings of the CRCIUFRO Conference, 19-24 February 1995, Hobart, Australia. Edited by B.M. Potts, N.M.G. Borralho, J.B. Reid, R.N. Cromer, W.N. Tibbits, and C.A. Raymond. CRC for Temperate Hardwood Forestry-IUFRO, Hobart, Tasmania. pp. 141-145.

Borralho, N.M.G. 2001. The purpose of breeding is breeding for a purpose. In Developing the Eucalypt of the Future. IUFRO International Symposium, 10-15 September 2001, Valdivia, Chile. Edited by S. Barros. INFOR, Chile.

Byers, D.L., Platenkamp, G.A.J., and Shaw, R.G. 1997. Variation in seed characters in Nemophila menziesii - evidence of a genetic basis for maternal effect. Evolution, 51: 1445-1456.

Cruzan, M.B., and Arnold, M.L. 1999. Consequences of cytonuclear epistasis and assortative mating for the genetic structure of hybrid populations. Heredity, 82: 36-45.

Dutkowski, G.W., and Potts, B.M. 1999. Geographical patterns of genetic variation in Eucalyptus globulus ssp. globulus and a revised racial classification. Aust. J. Bot. 46: 237-263.

Freeman, J.S., Jackson, H.D., Steane, D.A., McKinnon, G.E., Dutkowski, G.W., Potts, B.M., and Vaillancourt, R.E. 2001. Chloroplast DNA phylogeography of Eucalyptus globulus. Aust. J. Bot. 49: 831-835.

Gilmour, A.R., Thompson, R., Cullis, B.R., and Welham, S.J. 2001. ASREML reference manual. Technical Report. Orange Agriculture Institute, Orange, New South Wales, Australia.

Grose, R.J., and Zimmer, W.J. 1958. Influence of seed size and early growth of seedlings of Eucalyptus maculata Hook. f. and Eucalyptus sieberiana F.v.M. Bull. For. Comm. Victoria For. Tech. Pap. 9.

Harbard, J.L., Griffin, A.R., and Espejo, J. 1999. Mass controlled pollination of Eucalyptus globulus: a practical reality. Can. J. For. Res. 29: 1457-1463.

Helenurm, K., and Scaal, B.A. 1996. Genetic and maternal effects on offspring fitness in case of Lupinus texensis (Fabacea). Am. J. Bot. 83: 1596-1608.
Hewitt, N. 1998. Seed size and shade-tolerance: a comparative analysis of North American temperate trees. Oecologia, 114: 432-440.

Hodge, G.R., Volker, P.W., Potts, B.M., and Owen, J.V. 1996. A comparison of genetic information from open-pollinated and control-pollinated progeny tests in two eucalypt species. Theor. Appl. Genet. 92: 53-63.

Humara, J.M., Lopez, M., Casares, A., and Majada, J. 2000. Temperature and provenance as two factors affecting Eucalyptus nitens seed germination. Forestry, 73: 87-90.

Lacey, E.P. 1998. What is an adaptive environmentally induced parental effect? In Maternal effects as adaptations. Edited by T. Mousseau and C. Fox. Oxford University Press, New York. pp. 54-66.

Ladiges, P.Y. 1974. Differentiation in some populations of Eucalyptus viminalis Labill. in relation to factors affecting seedling establishment. Aust. J. Bot. 22: 471-487.

Leal, A.M.C., and Cotterill, P.P. 1997. Mass control-pollination of Eucalyptus globulus. In IUFRO Conference on Silviculture and Improvement of Eucalypts, 24-29 August 1997, Salvador, Bahia, Brasil. EMBRAPA, Colombo. pp. 256-258.

Lipow, S.R., and Wyatt, R. 1999. Diallel crosses reveal patterns of variation in fruit-set, seed mass, and seed number in Asclepias incarnata. Heredity, 83: 310-318.

Lopez, G.A., Potts, B.M., Dutkowski, G.W., Apiolaza, L.A., and Gelid, P.E. 2002. Genetic variation and inter-trait correlations in Eucalyptus globulus base population trials in Argentina. For. Genet. 9: 223-237.

Lopez, M., Humara, J.M., Casares, A., and Majada, J. 2000. The effect of temperature and water stress on laboratory germination of Eucalyptus globulus Labill. seeds of different sizes. Ann. For. Sci. 57: 245-250.

Lynch, M., and Walsh, B. 1998. Genetics and analysis of quantitative traits. Sinauer Associates, Inc., Sunderland, Mass.

Martins-Corder, M.P., Mori, E.S., Carvalho, M.T.V., and Derbyshire, E. 1998. Genetic diversity of three size classes of seeds of Eucalyptus globulus ssp. globulus. Silvae Genet. 47: 6-14.

Mazer, S.J., and Gorchov, D.L. 1996. Parental effects on progeny phenotype in plants - distinguishing genetic and environmental causes. Evolution, 50: 44-53.

Mazer, S.J., and Wolfe, L.M. 1998. Density-mediated maternal effects on seed size in wild radish. In Maternal effects as adaptations. Edited by T. Mousseau and C. Fox. Oxford University Press, New York. pp. 323-343.

McKinnon, G.E., Vaillancourt, R.E., Tilyard, P.A., and Potts, B.M. 2001. Maternal inheritance of the chloroplast genome in Eucalyptus globulus and interspecific hybrids. Genome, 44: 831-835.

Roach, D.A., and Wulff, R.D. 1987. Maternal effects in plants. Annu. Rev. Ecol. Syst. 18: 209-235.

Schmid, B., and Dolt, C. 1994. Effects of maternal and paternal environment and genotype on offspring phenotype in Solidago altissima L. Evolution, 48: 1525-1549.

Searle, S.R. 1971. Linear model. John Wiley \& Sons, New York.

Shaw, R.G., and Byers, D.L. 1998. Genetics of maternal and paternal effects. In Maternal effects as adaptations. Edited by T. Mousseau and C. Fox. Oxford University Press, New York. pp. 97-111.

Shaw, R.G., and Waser, N.M. 1994. Quantitative genetic interpretations of post pollination reproductive traits in plants. Am. Nat. 143: 617-635.

Stoehr, M.U., L'Hirondelle, S.L., Binder, W.D., and Webber, J.E. 1998. Parental environment aftereffects on germination, growth, and adaptive traits in selected white spruce families. Can. J. For. Res. 28: $418-426$. 
Vaillancourt, R.E., Potts, B.M., Watson, M., Volker, P.W., Hodge, G.R., Reid, J.B., and West, A.K. 1995. Detection and prediction of heterosis in Eucalyptus globulus. For. Genet. 2: 11-19.

van Wyk, G. 1976. Early growth results in a diallel progeny test of Eucalyptus grandis (Hill) Maiden. I. A field study. Silvae Genet. 25: $126-132$.

van Wyk, G. 1977. Early growth results in a diallel progeny test of Eucalyptus grandis (Hill) Maiden. II. A greenhouse study. Silvae Genet. 26: 44-50.

van Wyk, G. 1990. Genetic improvement of timber yield and wood quality in Eucalyptus grandis (Hill) Maiden. Part I. Genetic parameters of growth characteristics. S. Afr. For. J. 153: 1-11.

Waser, N.M., Shaw, R.G., and Price, M.V. 1995. Seed set and seed mass in Ipomopsis aggregata - variance partitioning and inferences about postpollination selection. Evolution, 49: 80-88.
Watson, M., Williams, D., Potts, B., and Krygsman, M. 2001. Seed quality and early seedling growth in Eucalyptus globulus. In Developing the Eucalypt of the Future. IUFRO International Symposium, 10-15 September 2001, Valdivia, Chile. Edited by S. Barros. INFOR, Chile.

Williams, D.R. 2000. Flowering and seed production in Eucalyptus nitens. Ph.D. thesis, University of Tasmania, Hobart, Tasmania.

Williams, D.R., Potts, B.M., and Black, P.G. 1999. Testing single visit pollination procedures for Eucalyptus globulus and E. nitens. Aust. For. 62: 346-352.

Wu, H.X., and Matheson, A.C. 2001. Reciprocal, maternal and non-maternal effects in radiata pine diallel mating experiment on four Australia sites. For. Genet. 8: 205-212. 